\title{
A Study on the Transition of Women's Social Status in Contemporary Russia
}

\author{
Chen Shuang \\ (Shandong Women's University, Jinan 250300,China)
}

Key words: Russian Women; transformation; social status; transition

\begin{abstract}
It has been more than 20 years since the collapse of the Soviet Union in December 1991, during which the successor States of the former Soviet Union, the Russian Federation, implements a series of reform s. Russia has deve loped greatly at all levels of social life, and Russian wom en's social status has changed as well in the transform ative period. In this paper, changes of the Russian woman's social status in the past 20 years have been combed entirely and deeply analyzed.
\end{abstract}

\section{Introduction}

It has been more than 20 years since the Soviet Union collapsed, and the contemporary Russia is now being in a transform ative period of social sy stem. Russia has transited from planned economy to market economy in economy and has carried out the democratic election system in politics. The Russian women's status has experienced a process from sudden deterioration to gradual steadiness and even steady rise in political, economic, and cultural life.

\section{A. The Transition and Its Reasons for Contemporary Russian Women's Social Status in the} States

1) The Russian W omen's Political $S$ tatus Has Experienced a Process fr om Deterioration to Gradual Rise in the Past 20 Years

In the early period of the Soviet U nion's collapse, to the situations of the wom en's post in Russian Federation and every main area of legislation, justice, and en forcement, the political status of Russian women was worsen seriously.

Russian Federation and Local Legislatives

At the beginning of the Soviet Union' s collapse, the quantity of fe male deputies in the Upper House of Russian Federation is ve ry low. Among the 178 mem bers in the Upper House, there just was only one female deputy in 1993 and 1995 as well as 1999, there were 3 fem ale deputies in the Upper House.

In the Low er House (the $\mathrm{S}$ tate Duma)'s three elections before of Russian federation, the proportion of female member also have a successi ve decline of $13.6 \%, 10 \%$ and $7.6 \%$ respectiv ely. In some organizations campaigning for party s eats, only the first session had the women' $\mathrm{s}$ organization called the Russian wom en's campaign, which never appear again in the following several sessions.

In the Duma's kinds of comm ittees, female leaders often belong to s ome softer comm ittees instead of the decision areas of national development in politics and economy as well as their latter signatures on many lists of vice-chairman.

In the 89 main local Congress of Russia, the number of female deputies is similar to Congress of the Union, for there is even no any fe male deputy at some regions. It th e third session of local Duma, the female deputies were not only few but al so responsible for the social education work, etc.

2) Federation and Local Judicial Field

In the colla pse of the Sovi et Union at the end of $20^{\text {th }}$ century, the judici al authority of the Federation, like the Rus sian Federal Constitutional Court, the Supreme Court of arbitration, there were only two women among the 40 highest leaders and no fem ale leader in the Supreme Court of arbitration's leadership. In the leadership of local judicial authorities, the situation of female leaders is similar to the Federal Government, and some regions' were even worse.

3) Federation and local executive authorities 
In the third session of R ussian Federal Government, there were a total of 74 of ficials among the ministerial level while only 3 women, including a Deputy Prim e Minister. Neither the am ong 7 special representatives of the president in 7 Federal District Federal District dispatched by President Putin nor the 89 Russian main local chief executives have no women.

With the stability of Russian politics and the speeded-up pace of economic development, Russian entered in $21^{\text {st }}$ century. The Russian wom en's economic status has been raised significantly, and their independence consciousness has been strengthened, as well as their requirements of politics have been increased. According to statistics, at present the Russian women's organizations of different level are more than 400, including 5 nationa 1 levels, 17international levels for the rest of local levels.

Russian women have been struggling persistently fo $r$ their rights. According to statistics, in the fifth session of the Federal C ouncil (Upper House), female members accounted for $4.9 \%$ ( $0.5 \%$ in 1998).The female members of the $\mathrm{S}$ tate Duma are 61 , accounting for $14 \%(10 \%$ in 1998$)$. The female members of federal main local meeting accounted for $12 \%$. There is a significant increase in the number of women in politics. By 2011 there have been 3 female ministers among the Russian Federation 26 ministers.

In administrations of all levels, wom en also are in majority. (Women account for $58 \%$ in the legislature, $70 \%$ in executing or gan and $79 \%$ in pr ocuratorial authorities). Female senators in political parties of the State Duma increase by years as well. Female senators account for $41.12 \%$ in local elections in 2012, with an increase from 39.78\% in 2011.

As what have been $m$ entioned above, despite some improvement in Russian wom en's political participation, there still is a long distance from political equality between male and f emale. Generally speaking, women in Russia have not acquired high political status, and when compared to women in Europe and U.S., there is still a huge disparity between them.

\section{B. The Reasons for the Changes of Russian Women's Social Status in the Recent 20 Years}

1) The Effect of Social Traditional Thoughts

In the Soviet Union's first constitution, it dete rmined the equality between men and women and women had the right to vote and be elected. In the construction of socialism, women's cultural level and status in the society increas ed day by day the in Soviet Union. The proportion of wom en participating in government and political af fairs was higher in Soviet tim es, especially in the late Soviet Supreme elections. The proportion of fem ale members promoting the election ever reached $34.5 \%$. The number of women cadres in govern ment agencies also acco unted for a proportion, but these women leadership, which represented through the women of the communist party committees. They had political power in theory, in fact, they lacked of political power, for women rarely entered the decision making power--the Politburo, in the practical politics.

After the so cial transition, the original system of selection $w$ as displaced by free co mpetition. The female politicians who have never gained the rights of participating in government and political affairs are at sea, and the social groups are difficult to understand why the female should participate in the policy making and executing. In the m eantime, the group of wom en themselves also doubts the female politicians' capacity. Social and women consciously consider that fem ale should be the participator of social politics and construction rather than the decision maker.

2) The Incom plete Economic and Social Insurance System Make W omen Have No Overwhelming Interest on Their Political Status

In the early of the collapse of the Soviet Union, social transition result in the Russian econom ic downturn, and the poorer classes st arted to appear. The group of women was shocked at first. A large number of women lost their job, even reached $80 \%$ of the total unemploym ent. The government reduced the investm ent of education and health, making the mother can not get the social Insurance. Women did everything just for lives, so they were unconcerned about political.

3) The Effect of Women's Organizations

At the same time, a lot of Russian wom en's organization and non-governm ental organization appeared. From 1993 to 1995, they had registered women's organization about 400. They seldom participated in political cam paigns and coor dinated and cooperated with other wom en's 
organization in different areas. They just worked to help women get back to work and improve their living conditions.

In recent years, Russia wom en's organizations have already realized it, and they have attem pted to unite all sectors of society to fight for the equality of men and women.

\section{Russian Women's Status in the Economic Life in Recent 20 Years}

\section{A. Russian Women's Pauperization in the Early of the Soviet Union's Collapse}

In the 1990s, planned economy transformed into market mechanism, Russian women became the biggest victim, une mployment stayed higher. From 1991 to 1998, the wo men accounted for two thirds of the 12 million unemployed populations, 8 million, and some area's proportion even reach up to $90 \%$. Therefore, the working women had higher education level than the man, but women and man had the unequal employment opportunity, they faced the bigger threat of losing their jobs.

There are many aspects to explai $n$ the reasons why it' $s$ hard to improve the economic statue of women in Russia. Firs tly, large-scale privatization reforms have made the national economy declining. A large number of state-owned assets $\mathrm{c}$ oncentrated in the hands of groups of $\mathrm{m}$ en, and women have become a drag on business transform ation. Therefore a lot of women leave their jobs, and lose a stable source of incom e. Many wo men earn a living by doing odd jobs, and others go back their hom e and part as a housewife. Secondly, the soci al conception, w hich holds the discrimination and rejection to women entrepreneurs, also press the difficulty of women's business. Thirdly, the state is lack of suppor ting re-employment measures, the sti pulations of law about gender equality in the econom ic sphere are $\mathrm{d}$ estructed for m any times. The equ al thoughts of employment between men and women don't gain the social recognition.

\section{B. The Contemporary Russian Women in the Workplace}

1) The Sign ificant Increasing Em ployment Rate of Russia Fem ale in Recent Y ears VS. Their Low Position in the Workplace and Lower Salary than Men

For the employment situation of women in the early period of Soviet Un ion' collapse, Russian women and wom en's organizations in all walks of life take $m$ easures actively to minimize the impact of the reform as little as possible, and help women to get out of troubl e. In recent years, the condition of Russian women in the labor market has been improved apparently.

$\mathrm{PhD}$ in Sociology, Kryshtanovskaya says that Russian W omen has made a breakthrough in business. Many of them get the high positions and high wages, which have a deep im pact on Russian society. Family condition, which is dominated by $\mathrm{m}$ an, has been a past. In 2009, the operational ratio of All-Russian citizens with labor capacity: men 73.7\%, females $62 \%$.

In addition to trad itional "male" occupations: construction, fishing, mining, etc., and the employment rate of women in other industries accounts for the vast majority.

Average monthly wage of men and women: Male: 240,000 roubles, female $: 156,000$ roubles.

The unemployed, women accounted for $7.9 \%$, men accounted for $8.4 \%$.

Russia female received a high leve 1 of education, but there is $\mathrm{s}$ till low proportion of fe male in leadership positions. Most of them engage in some less demanding on technology and low paid jobs, and even some of the dirty work. On the other hand, the average monthly wage of men and women also confirmed this point.

2) Some Russian Women Begin to Run a Small Business and Succeed.

Female are careful and m eticulous to the work, and have a flexib le attitude toward cooperation, also Russia women receive higher level education, which determines that women have made great achievements in the business under the same conditions. According to the Ministry of Labor of Russian Federation, wom en, and children, in recen $t$ years, $70 \%$ of Russian wom en are study ing economics and management, and they are striving to develop their own busin ess. For the needs of society, there was a lar ge number of training cour ses nurturing the future women entrepreneurs, especially at photographic enlargements, sewing, hairdressing, food and other aspects. The number of female workers in financial industry is up to $70 \%$. Also, a lot of wom en are engaged in trading company managers and agents. Because of endur ing hardships and working hard, $m$ any Russia 
women obtain the su ccess through struggling by themselves under the condition of lacking fun ds and loaning hardly. These small and medium enterprises are mostly concentrated on light industry, service sector, art and other traditional "female" sections.

3) The Share of Female Senior Managers Is Increasing.

Recently, a survey, which includes 76 com panies, shows that the share of fem ale leaders is increasing from 2008 to 2010 . Female account of the vast majority on Chief: (91\%), 65\% of HR managers, $49 \%$ of financial $\mathrm{m}$ anagers. At the sa me time, the number of female chairman is increasing. The number of female chairman of the 2010 is double than 2008.

The features of the female determine that the female staff is more loyal and reliable. In $37 \%$ of the interviewed com panies, female employees work longer than $\mathrm{m}$ en on average. $42 \%$ of the interviewed companies show that the female candidates accept higher level education and possess more necessary vocational skills. Fourth companies consider that the fem ale can display higher level working ability and hard-w orking spirit. $20 \%$ of com panies think that wom en have psychological preparation on low pay.

Since the increase of female managers, companies begin to focus on the protection of women's rights when they develop policies. In the interviewed companies, there are $8 \%$ of companies having stipulations to protect the women's rights. More and more companies allow mothers of infants with flexible working hours. According to survey, such companies account of $25 \%$ in 2010 , and $39 \%$ in 2011. $9 \%$ of the company developed a regression of women when they finish the maternity leave and more than half of the women care for 1 to 2 years old children at home.

\section{The Change of Contemporary Russian Women's Status in Marriage and Family}

\section{A. The Changes of Female Status in Family in the Past 20 Years}

After the collapse of the Soviet Union, female become the main provider of the fam ily. Former Soviet subverted the traditional patriarchal society, women were given equal righ ts with men, so that women are no longer a $\mathrm{m}$ en's appendage. In th e former Soviet U nion, raising a fa mily is no longer the men; women's wages has become an important source of household income, which plays an important role in family income.

After the Soviet Union's collapse, great change s have taken place. Many companies with high wages, good payment and good prestige shut down s uddenly. A large number of men working in these sectors lost their job. Not only had they lost wages but professi onal skills, so that women feel a great sense of responsibility. They have to fort h to feed their fam ilies; Russian women's tough, hard-working tradition has been the greatest play. The Russian wom en adapted to social change with the fastest speed, they did not care about social status, whether the work was decent, the most important thing for them was to support the family.

The younger generations of Russian wom en are affected by dem ocracy politics, their values change with the changes of econo mic status, and they have a str onger sense of independence, a greater emphasis on equality and extend individuality. They worship personal struggle and success. They are no longer satisfied to m arry a rich husband, be a full-time wife at home, help the husband and teach the children.

They know freedoms and rights are built on econom ic foundations, so they rely o $\mathrm{n}$ their own labor income, and spend their money according to their willing. In their view, work not only can bring economic income, but more of a way of life, which is a way to obtain so cial status and social approval.

\section{B. The Diversification of Family Pattern}

Compared with the former Soviet Union, there has been a diversifie d trend of family patterns in today's Russia, and wom en are free to choose lif estyles suited to them. For Russian wom en, children are the $m$ ost important components of th e family; raising children reflects a wom an's greatest value. Com pared with the Soviet peri od, the marriage rate in contem porary Russia falls while divorce rate rises; In addition to the $r$ eason of deterioration of family economy, the consciousness of male members supporting the fa mily lessens; "sexual liber ation" becomes more prevalent with sexual need is not fully consistent with $\mathrm{m}$ arriage; non-marital cohabitation, 
premarital sex and other relative ly common phenom enon, also, prev ail. So the wom en no longer consider that marriage is the only way to raise children. According to the survey from Casino Victor Company in 2008, 56\% of women thi nk that if they can't find their right husband, they should at least raise their own childr en. It is not to say th at husband is not im portant, but children are the symbol for Russian wom en's highest value. These ideas also show a growth in Russian wom en's awareness of female independence. From Casino Victor Company's report in March 2008, we get the knowledge that $90 \%$ of women believe that unmarried women can make greater achievement in their career.

Highly educated and hard-working, Russian w omen's social s tatus and role of the workplace become increasingly significant. At the sam e time, the men who suit them are rare, so the more achievements they get, the more loneliness they get. If portrayed, the contemporary Russian women should be: hard-working, kids first, eager to get lovers' care and attractive.

\section{Conclusions}

According to the 2010 census results across the country, Russia's population is 142.905 million, with 66.205 million men, accounting for $46.3 \%$ and 76.7002 million women, accounting for $53.7 \%$. Female population increased by $0.3 \%$ compared with that in 2002 in which $m$ en accounted for $46.6 \%$ of the total population and women accounted for $53.4 \%$. In aspect of po pulation, Russian women have been dom inant all the tim e. But Russian women are still in a subo rdinate position in many other aspects of life. Economic advancement, changes of traditional values and enhancement of independent consciousness have caused a great contradiction for Russian women with the real social status of them. Thus, there still have a long way for the Russian women to go to eliminate discrimination and campaign for equality.

\section{References}

[1] Seven S teps to Success for W omen. Regional Social and Econom ic Development Strategy before 2020.Notice of Kirov State News Center, 2008.

[2] Women and Developm ent: Power, Reality and Prospect. Conf erence on Men and W omen's Status in Russia, 1999.

[3] Feminist and Gender Policy. Textbook. Business Press Group, 2007.

[4] Russian Women's Movement in the Process of Modern Society. Sims Press, 1999.

[5] Their W ork on t he Rise, Their Rights in the Narrow . Regional social and Econom ic Development Strategy before 2020.Notice of Kirov State News Center, 2003.

[6] LanYingbo. The Changes of Russian wom en's Social Status during the Period of Social Transformation. [J] Journal of Xuehai, June 2008.

[7] Song Zhaojie, Zhou Libin. An Analysis on the Feminization Tendency of Soviet Union-Russia's Scientific Research Personnel Proportion assu mes [J]. Sc ience and T echnology Management Research, September 2010. 